\title{
EKSPRESI p53 DAN E-CADHERIN SEBAGAI PREDIKTOR PROGNOSIS PADA KARSINOMA SEL SKUAMOSA RONGGA MULUT DI RSUP DR. KARIADI SEMARANG
}

\author{
Clara Pangaribuan ${ }^{1}$, Udadi Sadhana ${ }^{2}$, Meira Dewi Kusuma Astuti ${ }^{2}$, Dik Puspasari $^{2}$, Devia Eka \\ Listiana $^{2}$, Ika Pawitra Miranti ${ }^{2}$ \\ ${ }^{1}$ Residen Patologi Anatomik, Fakultas Kedokteran Universitas Diponegoro - RSUP dr. Kariadi \\ Semarang \\ ${ }^{2}$ Dosen Patologi Anatomik, Fakultas Kedokteran Universitas Diponegoro - RSUP dr. Kariadi \\ Semarang
}

Email korespondensi : pangaribuanclara@gmail.com

\begin{abstract}
Abstrak
Latar belakang : Karsinoma sel skuamosa rongga mulut (KSSRM) memiliki prognosis yang buruk ditandai dengan angka kecacatan dan kematian terutama bila sudah ada metastasis. Ekspresi p53 dan E-cadherin diharapkan membantu penilaian prediksi progresifitas dan prognosisnya.

Tujuan: Menghitung ekspresi p53 dan E-cadherin pada pasien KSSRM dengan dan tanpa metastasis di RSUP dr. Kariadi Semarang.

Metode: Merupakan penelitian observasional analitik dengan rancangan desain cross sectional. Sebanyak 33 blok histopatologi RSUP dr.Kariadi Semarang dengan diagnosis karsinoma sel skuamosa rongga mulut tahun 2015-2018 dilakukan pengecatan immunohistokimia antibodi p53 dan E-cadherin. Analisa hasil dengan menggunakan Uji Mann Whitney, apabila nilai $p<0,05$ maka hasil tersebut dinilai bermakna.

Hasil: Pada analisa Mann Whitney terdapat perbedaan tidak bermakna untuk p53 ( $p=0,056)$ antara pasien KSSRM tanpa dan dengan metastasis. Pada E-cadherin terdapat perbedaan bermakna $(\mathrm{p}=0,001)$ antara kelompok KSSRM tanpa metastasis dengan kelompok metastasis.

Kesimpulan: Ekspresi imunohistokimia E-cadherin dapat menjadi prediktor prognostik pada KSSRM tetapi dibutuhkan penelitian lebih lanjut.
\end{abstract}

Kata kunci : karsinoma sel skuamosa rongga mulut, metastasis, p53, E-cadherin 


\title{
P53 AND E-CADHERIN EXPRESSION AS PREDICTORS OF PROGNOSTIC IN ORAL SQUAMOUS CELL CARCINOMA AT KARIADI HOSPITAL SEMARANG
}

\author{
Clara Pangaribuan ${ }^{1}$, Udadi Sadhana ${ }^{2}$, Meira Dewi Kusuma Astuti ${ }^{2}$, Dik Puspasari ${ }^{2}$, Devia Eka \\ Listiana ${ }^{2}$, Ika Pawitra Miranti ${ }^{2}$ \\ ${ }^{1}$ Resident of Pathology Department, Medical Faculty, Diponegoro University-Kariadi Hospital,
Semarang
${ }^{2}$ Lecturer of Pathology Department, Medical Faculty, Diponegoro University-Kariadi Hospital,
}

Semarang

Corresponding email : pangaribuanclara@gmail.com

\begin{abstract}
Background : Oral squamous cell carcinoma (OSCC) has poor prognostic. The incidences of mortality and malformation were higher in patients with local invasion and metastasize to regional lymph node. The immunohistochemistry expression of p53 and E-cadherin could be used as predictor progressivity and prognosis in OSCC.

Objective : Investigate p53 and E-cadherin expression in OSCC patients with and without metastasis in Kariadi Hospital Semarang.

Methods: This is a cross-sectional analytical study of thirty three samples. Thirty three paraffin blocks of oral squamous cell carcinoma from Kariadi Hospital Semarang (period 2015 to 2018) were be stained with $p 53$ and E-cadherin antibody. The data was processed analytical using Mann Whitney Test methods with a significance value of $p<0.05$ was considered significant.

Results : In the Mann Whitney analysis, there were no significant differences in p53 expression $(p=0,056)$ between OSCC patients with and without metastasis. There were significant differences in E-cadherin expression ( $p=0,001)$ between OSCC patients with and without metastasis.

Conclusion : Expression of E-cadherin could be a predictor of prognostic in OSCC but need to be studied further.
\end{abstract}

Keywords : Oral squamous cell carcinoma, metastasis, p53, E-cadherin 


\section{PENDAHULUAN}

Karsinoma sel skuamosa rongga mulut (KSSRM) merupakan keganasan yang berasal dari epitel mukosa rongga mulut. Kanker ini adalah jenis terbanyak untuk keganasan rongga mulut (lebih dari $90 \%$ dari seluruh jenis kanker rongga mulut). ${ }^{1}$ Di Indonesia menurut data Analisis Riskesdas 2007 ; 2-5\% dari seluruh keganasan merupakan kanker rongga mulut, sedangkan di tahun 2012 tercatat sebanyak 5.329 penderita dan diperkirakan meningkat sebanyak $21,5 \%$ di tahun $2020 .^{2}$ Walaupun sudah melakukan pendekatan melalui terapi, lokasi, dan stadium penyakit, tetapi sekitar lebih dari $50 \%$ pasien mengalami relaps, akibatnya diperlukan pengetahuan mengenai mekanisme progresifitas KSSRM dan tanda progresifitas tumor. Tanda progresifitas tumor adalah kemampuan sel tumor menginvasi jaringan sekitar melewati membrana basalis, yang disebabkan oleh karena adanya kelemahan adhesi antar sel sehingga terjadi disosiasi. ${ }^{3}$ Kejadian mutasi p53 sendiri merupakan fenomena umum dari KSSRM. ${ }^{4}$ Protein p53 berperan sebagai penjaga integritas genom yang melindungi dan mencegah sel-sel bertransformasi menjadi ganas. Pada siklus sel, p53 bertugas mengenali sel yang menyimpang dan menghentikan pertumbuhan sel tersebut, sehingga diharapkan sel yang menyimpang dapat diperbaiki atau dilakukan apoptosis untuk menghentikan pertumbuhan sel-sel tersebut. Pada tumor dengan p53 mutan akan membentuk tingkat agresifitas tumor yang tinggi dan lebih mudah bermetastasis dibanding p53 normal. ${ }^{5}$ Pada penelitian Buim et al, ${ }^{6}$ Zanaruddin et al, ${ }^{7}$ dan Yang et al, ${ }^{8}$ menyebutkan bahwa perbedaan ekspresi p53 tidak signifikan dengan parameter klinikopatologi termasuk status kelenjar getah bening. Hasil berbeda didapatkan pada penelitian Jasmeet Kaur et $a{ }^{9}{ }^{9}$ dan Tjok et al $^{10}$ yang mengemukakan bahwa p53 dapat menjadi indikator prognosis dan prediktor untuk kasus KSSRM.

Salah satu ciri keganasan adalah kemampuan sel-sel abnormal untuk menginvasi dan bermetastasis ke jaringan sekitar. Sel-sel epitelial rongga mulut terhubung satu dengan lainnya oleh ikatan erat adhesi antar sel yang dimediasi oleh cadherin. Cadherin merupakan suatu protein transmembran calcium dependent, yang diantaranya terdapat suatu protein khusus yang terekspresi di epitelial dan dikenal sebagai E-cadherin. ${ }^{3}$ Hasil penelitian Zhou et al, $^{11}$ dan Lim et $a l,{ }^{12}$ mengkonfirmasi adanya mekanisme epigenetik dan kemungkinan E-cadherin dapat menjadi salah satu parameter prognostik untuk pasien KSSRM. Perbedaan hasil ditemukan pada penelitian Balasundaram et al, yang menyatakan tidak ada perbedaan bermakna pada ekspresi E-cadherin antara kasus KSSRM metastasis dan tidak metastasis. ${ }^{13}$ 
Penelitian ini menilai apakah ada perbedaan ekspresi immunohistokimia p53 dan E-cadherin pada pasien KSSRM dengan metastasis dan tidak metastasis di RSUP dr. Kariadi Semarang.

\section{METODE PENELITIAN}

Penelitian observasional analitik dengan desain cross sectional. Populasi penelitian adalah blok parafin yang terdiagnosis KSSRM periode 1 Januari 2015 sampai dengan 31 Desember 2018. Penelitian ini menggunakan 33 sampel kasus KSSRM dengan 16 kasus metastasis dan 17 kasus tanpa metastasis, yang telah memenuhi kriteria inklusi untuk dievaluasi p53 dan E-cadherin secara immunohistokimia.

Setelah dilakukan pemotongan blok parafin dan melalui proses awal, sediaan diinkubasi dengan antibodi p53 (Monoclonal Rabbit p53 Diagnostic Bio System) dengan pengenceran 1:100 dan antibodi E-cadherin (Monoclonal Rabbit E-cadherin Cell Marque) prediluted ready-to-use. Proses dilanjutkan dengan inkubasi menggunakan antibodi sekunder biotinylated universal secondary antibody (Univeral-Kit : LSAB2 system-HRP, Ref : K 0673, 026011 dari Dako Co) kemudian sediaan diinkubasi dengan DAB. Proses dilanjutkan dengan pemberian counterstain menggunakan Mayer's Haematoxylin, dan dehidrasi menggunakan alkohol konsentrasi meningkat, selanjutnya dilakukan clearing dengan xylol dan kemudian ditutup dengan kaca penutup menggunakan mounting (Entelan, cat : 1.07961 dari MERCK)

Antibodi p53 dikatakan positif apabila tercat coklat pada inti sel tumor dan antibodi E-cadherin dikatakan positif apabila tercat coklat di membran sel tumor. Penilaian ekspresi immunohistokimia p53 dan E-cadherin dilakukan secara semikuantitatif menggunakan skor Allred. Metode skor Allred menghitung jumlah proporsi sel-sel skuamosa yang mengalami proliferasi beserta penilaian terhadap intensitas pengecatan. Daerah tumor kemudian difoto sebanyak lima lapang pandang besar (pembesaran 400 kali) menggunakan mikroskop kamera Leica DM750 untuk setiap kasus, kemudian dibaca oleh dua orang ahli patologi anatomi secara membuta. 


\section{HASIL}

Penelitian ini didapatkan data karakteristik sampel (tabel 1) KSSRM di RSUP dr. Kariadi periode tahun 2015 sampai dengan 2018 lebih banyak terjadi pada laki-laki sebanyak 57.8\%, KSSRM juga lebih banyak terjadi pada pasien berusia lebih dari 50 tahun, sedangkan untuk derajat diferensiasi ditemukan hanya dua derajat diferensiasi, terbanyak adalah diferensiasi baik sebanyak $66,67 \%$, dan lokasi tersering KSSRM di penelitian ini adalah pada lidah sebanyak 18 kasus $(54,55 \%)$.

Tabel 1. Frekuensi dan persentase $\div$ jenis kelamin, usia, derajat diferensiasi, lokasi dan ada tidaknya metastasis

\begin{tabular}{llll}
\hline \multicolumn{1}{c}{ Variabel } & & Jumlah (orang) & Persentase \\
\hline \multirow{2}{*}{ Jenis kelamin } & Pria & 19 & $57,58 \%$ \\
\cline { 2 - 4 } & Wanita & 14 & $42,42 \%$ \\
\hline \multirow{2}{*}{ Usia } & $\leq 50$ tahun & 15 & $45,45 \%$ \\
\cline { 2 - 4 } & $>50$ tahun & 18 & $54,55 \%$ \\
\hline \multirow{2}{*}{ Derajat diferensiasi } & Baik & 22 & $66,67 \%$ \\
\cline { 2 - 4 } & Sedang & 11 & $33,33 \%$ \\
\hline \multirow{3}{*}{ Lokasi } & Lidah & 18 & $54,55 \%$ \\
\cline { 2 - 4 } & Buccal & 7 & $21,21 \%$ \\
\cline { 2 - 4 } & Bibir & 2 & $6,06 \%$ \\
\cline { 2 - 4 } & Lainnya & 6 & $18,18 \%$ \\
\hline \multirow{2}{*}{ Metastasis } & Ya & 16 & $58,49 \%$ \\
\cline { 2 - 4 } & Tidak & $17.51 \%$
\end{tabular}

Jumlah kasus keganasan rongga mulut periode tahun 2015 sampai 2018 di RSUP dr. Kariadi didapatkan kasus terbanyak di tahun 2015 dan jumlah kasus paling sedikit di tahun 2017. Tipe histopatologi keganasan rongga mulut periode tahun 2015 sampai 2018 di RSUP dr. Kariadi terbanyak adalah karsinoma sel skuamosa sebanyak $49 \%$. 


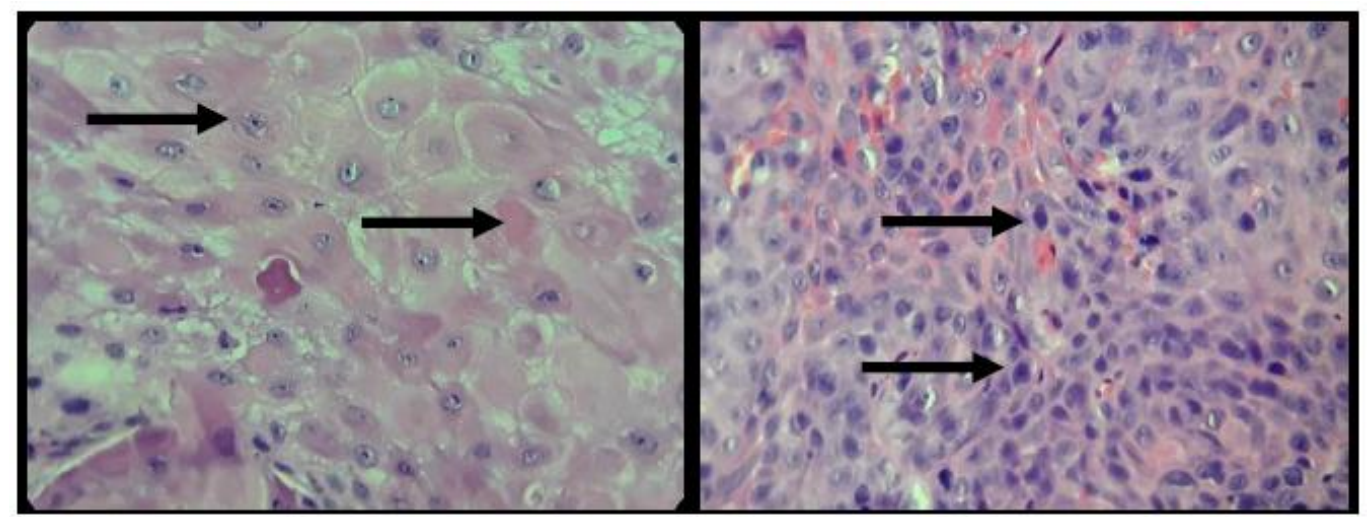

Gambar 1. Pengecatan Hematoxylin Eosin dengan pembesaran 400X tampak karsinoma sel skuamosa rongga mulut diferensiasi baik (kiri), diferensiasi sedang (kanan)

Berdasar uji non parametrik Mann Whitney (tabel 2) perbedaan dikatakan bermakna apabila $p<0,005$. Pada penelitian ini didapatkan perbedaan rerata skor ekspresi $p 53$, ditandai dengan kelompok metastasis lebih tinggi daripada kelompok tidak metastasis namun tidak bermakna $(p=0,056)$. Hasil uji non parametrik Mann Whitney pada ekspresi immunohistokimia E-cadherin pada kelompok tidak metastasis dengan kelompok metastasis, didapatkan perbedaan yang bermakna $(p=0,001) .($ Tabel 2$)$

Tabel 2. Perbedaan p53 dan E-cadherin berdasarkan ada tidaknya metastasis

\begin{tabular}{lccc}
\hline \multirow{2}{*}{ Variabel } & \multicolumn{2}{c}{ Kelompok } & \multirow{2}{*}{$\mathbf{P}$} \\
\cline { 2 - 3 } & Tidak Metastasis & Metastasis \\
\hline p53 & $5,8(3,4-7,2)$ & $6(5,6-6,8)$ & $0,056^{\ddagger}$ \\
E-cadherin & $7,4(5,4-8)$ & $6,4(5,6-7,4)$ & $0,001^{\ddagger \star}$ \\
\hline
\end{tabular}

Keterangan : ${ }^{*}$ Signifikan $(p<0,05) ;{ }^{\ddagger}$ Mann Whitney
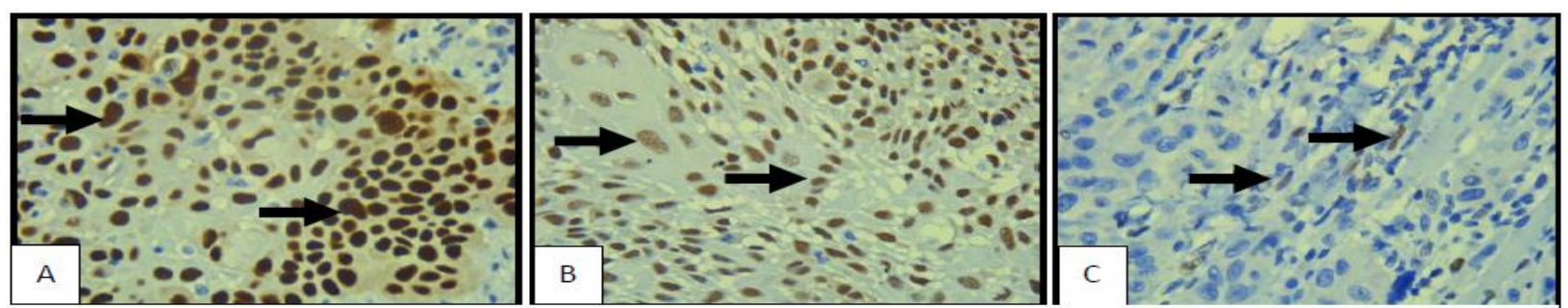

Gambar 2. Ekspresi immunohistokimia p53 dengan pembesaran $400 \mathrm{X}$, positif pada inti sel tumor dengan intensitas kuat $(A)$, sedang $(B)$, dan lemah $(C)$

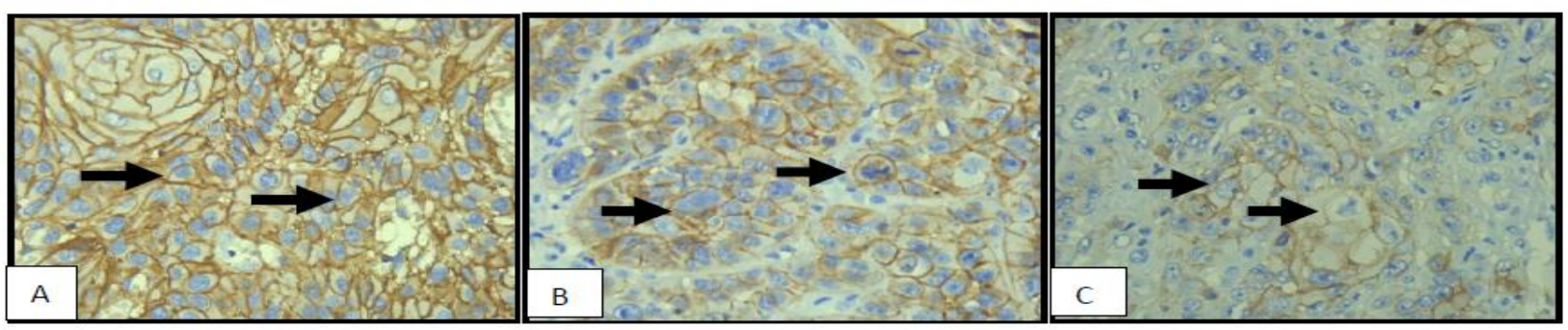

Gambar 3. Ekspresi immunohistokimia E-cadherin dengan pembesaran 400X, positif pada membran dengan intesitas kuat (A), sedang (B). dan lemah (C) 


\section{PEMBAHASAN}

Nama p53 berasal dari suatu protein dengan berat molekul 53.000 unit massa atom. Pada suatu keadaan tanpa tekanan maka p53 akan inaktif, tetapi ketika terdapat suatu stres, p53 akan mengenali kerusakan DNA (Deoxyribonucleic acid) dan melakukan tindakan untuk memperbaiki DNA rusak atau memaksa sel tersebut untuk melakukan bunuh diri sel, yang dikenal sebagai apoptosis. Kejadian KSSRM sangat berkaitan dengan mutasi p53. ${ }^{14}$ E-cadherin merupakan calcium dependent protein membran yang berasal dari family cadherin. Peranannya yang semakin jelas, tidak hanya terbatas pada mekanisme adhesi antar sel tetapi juga untuk morfogenesis termasuk pengenalan sel, pembentukan dan perawatan formasi serta struktur sel, koordinasi pergerakan sel, fungsi dan polaritas jaringan. Berdasarkan fungsi-fungsi tersebut tidak mengherankan bahwa E-cadherin berhubungan dengan jaringan normal sampai dengan metastasis karsinoma. ${ }^{3}$

Hasil data karakteristik kasus KSSRM didapatkan lebih banyak terjadi pada laki-laki, sesuai dengan kepustakaan yang menyebutkan bahwa rasio laki-laki lebih tinggi daripada perempuan. ${ }^{1,8,11}$ Hal ini dikaitkan dengan paparan faktor risiko yang lebih sering terpajan pada laki-laki. ${ }^{15}$ Pada populasi penelitian Buim et al, ${ }^{6}$ sebagian besar merupakan laki-laki sebanyak $79 \%$ dari keseluruhan sampel penelitian dengan riwayat paparan faktor risiko yaitu kebiasaan konsumsi tembakau ataupun alkohol yang lebih tinggi dibanding perempuan. Sedangkan hasil yang berbeda ditemukan pada penelitian di Mexico oleh Guerrero et $a{ }^{16}{ }^{16}$ yang menyebutkan rasio perbandingan laki-laki dan perempuan hampir sama, disebabkan oleh kebiasaan merokok dan minum alkohol yang juga sering dilakukan oleh perempuan di negara tersebut. Penelitian ini juga menemukan kasus KSSRM lebih banyak terjadi pada pasien berusia lebih dari 50 tahun, sesuai dengan penelitian Zhou et al, ${ }^{11}$ Balasundaram et $\mathrm{al}^{13}{ }^{13}$ dan kepustakaan WHO Classification of Head and Neck Tumor tahun 2017 yang menyebutkan KSSRM banyak ditemukan pada usia 50 sampai 70 tahun. ${ }^{1}$ Kejadian ini diakibatkan oleh paparan faktor risiko yang terus meningkat seiring usia, sehingga apabila ditemukan kejadian KSSRM di usia muda harus dipikirkan adanya riwayat keluarga yang mengalami keganasan sebelumnya. Menurut penelitian Philip et $a l,{ }^{15}$ terdapat latensi selama 25 tahun sejak paparan karsinogen pertama kali sampai timbulnya gejala klinis karsinoma. Sedangkan untuk derajat diferensiasi, didapatkan lebih banyak KSSRM diferensiasi baik sebanyak 66,67\%, sesuai dengan kepustakaan WHO Classification of Head and Neck Tumor tahun 2017, ${ }^{1}$ penelitian Balasundaram et $a l,{ }^{13}$ dan Vicente et al. ${ }^{17}$ Lokasi tersering KSSRM di penelitian ini adalah pada lidah sebanyak 
18 kasus $(54,55 \%)$ sesuai dengan peneltian Zhou et al. ${ }^{11}$ Lokasi terbanyak di lidah juga didapatkan pada kasus-kasus KSSRM di negara barat, disebabkan karena kebiasaan merokok di negara tersebut. Hal yang berbeda ditemukan pada penelitian di negara India dan Asia Tengah, dengan prevalensi KSSRM lebih banyak pada daerah mukosa buccal, hal ini berkaitan dengan kebiasaan penggunaan tembakau yang diselipkan diantara gingiva dan buccal. ${ }^{15}$

Berdasarkan hasil penelitian untuk ekspresi immunohistokimia p53 pada kelompok tanpa metastasis dengan kelompok metastasis, didapatkan adanya perbedaan namun tidak bermakna, karena nilai $p$ yang didapat $>0,05$. Perbedaan dua kelompok ini terlihat pada ekspresi p53 yang lebih tinggi pada kelompok metastasis. Gambaran ini didapatkan pula pada hasil penelitian Buim et al, ${ }^{6}$ Zanaruddin et al, ${ }^{7}$ dan Yang et al, ${ }^{8}$ disebutkan bahwa perbedaan ekspresi p53 tidak signifikan dengan parameter klinikopatologi termasuk status kelenjar getah bening. Hal ini dapat terjadi dikarenakan faktor risiko turut mempengaruhi ekspresi p53 terutama riwayat paparan tembakau. Insiden mutasi p53 lebih tinggi terjadi pada pasien-pasien dengan riwayat penggunaan tembakau. Penelitianpenelitian sebelumnya melaporkan bahwa perubahan mutasi p53 pada penggunaan tembakau maupun betel quid khususnya pada negara Asia berbeda signifikan dengan mutasi p53 di seluruh dunia. Perubahan tersebut juga diikuti dengan perubahan pola mutasi p53 sesuai dengan kebiasaan penggunaan tembakau. Pada pasien KSSRM dengan kebiasaan penggunaan tembakau tanpa asap, juga didapatkan perubahan pasangan basa dan multipel mutasi p53.

Selain itu perkembangan dan progresivitas tumor tidak hanya bergantung pada gen P53 yang merupakan tumor suppressor gene serta bertugas mengkode faktor transkripsi untuk menghambat proliferasi dengan penghentian siklus sel, namun terdapat pula gen-gen lain yang juga berperan dalam menghambat proliferasi sel apabila pertumbuhan sel tidak terkontrol. ${ }^{18}$ Hasil berbeda didapatkan pada penelitian Jasmeet Kaur et al, ${ }^{19}$ dan Tjok et al, ${ }^{10}$ yang mengemukakan bahwa p53 dapat menjadi indikator prognosis dan prediktor keterlibatan kelenjar getah bening, karena gen P53 merupakan gen penjaga genom, yang memiliki kemampuan mengenali DNA yang rusak dan mampu menghentikan siklus sel sehingga dihasilkan waktu untuk memperbaiki kerusakan tersebut, atau memaksa sel untuk apoptosis apabila tidak bisa diperbaiki lagi.

Penelitian ini dilakukan untuk menilai ekspresi immunohistokimia E-cadherin pada kelompok tidak metastasis dengan kelompok metastasis, didapatkan hasil berupa perbedaan yang bermakna antara kelompok KSSRM dengan metastasis dan kelompok tidak metastasis, terlihat dari ekspresi 
E-cadherin yang lebih tinggi pada kelompok tidak metastasis. Hasil ini menunjukkan semakin rendah ekspresi E-cadherin dapat menjadi penanda adanya kemungkinan metastasis atau prognosis yang lebih buruk. Hasil yang sama didapatkan pula pada penelitian Zhou et $\mathrm{al},{ }^{11}$ dan Lim et al, ${ }^{12}$ yang mengkonfirmasi mekanisme epigenetik dan kemungkinan E-cadherin dapat menjadi salah satu parameter prognostik untuk pasien KSSRM.

Hasil yang berbeda terlihat pada penelitian Balasundaram et al, ${ }^{13}$ yang menyatakan tidak ada perbedaan bermakna pada ekspresi E-cadherin antara kasus KSSRM metastasis dan tidak metastasis. Penelitian ini menyebutkan ekspresi E-cadherin dipengaruhi oleh jenis dan staging tumor tersebut.

\section{KESIMPULAN}

Terdapat perbedaan bermakna ekspresi imunohistokimia E-cadherin pada KSSRM kelompok metastasis dan tidak metastasis, ditandai dengan lebih tingginya ekspresi E-cadherin pada kelompok tidak metastasis. Hasil tersebut memungkinkan E-cadherin menjadi prediktor prognostik, tetapi dibutuhkan penelitian lebih lanjut.

\section{REFERENSI}

1. Naggar A, Chan J, Grandis J, Takata T, Slootweg P. WHO Classification of Head and Neck Tumours (4th Edition). 4th ed. Lyon: IARC; 2017.

2. Sirait A. Faktor Risiko Kanker/Tumor Rongga Mulut dan Tenggorokan di Indonesia. Media Litbangkes. 2013;23(3):122-129. ejournal.litbang.depkes.go.id/index.php/MPK/article/view/3281 Vo 23, No 3 (2013).

3. Hashimoto T, Soeno Y, Maeda G, et al. Progression of Oral Squamous Cell Carcinoma Accompanied with Reduced E-Cadherin Expression but Not Cadherin Switch. PLoS One. 2012;7(10):1-8. doi:10.1371/journal.pone.0047899

4. Urooj U, Zarina S, Pennington SR. Archives of Oral Biology Oral squamous cell carcinoma : Key clinical questions, biomarker discovery, and the role of proteomics. Arch Oral Biol. 2019;63(2016):53-65. doi:10.1016/j.archoralbio.2015.11.017

5. Herlia I, El A. Peran p53 Sebagai Jalur Kritis pada Mekanisme Kontrol Siklus Sel Sebagai Pencegah Terjadinya Kanker Mulut. J Dent Indones. 2002;9(2):30-34. 
6. Eliza M, Buim C, Fregnani JH, Lourenço SV, Nagano CP, Lopes A. Journal of Molecular Biomarkers Prognostic Value of Cell Cycle Proteins in Squamous Cell Carcinomas of the Oral Cavity. J Mol Biomark Diagn. 2011;2(3):1-9. doi:10.4172/2155-9929.1000111

7. Nurain S, Zanaruddin S, Yee PS, et al. Common Oncogenic Mutations Are Infrequent in Oral Squamous Cell Carcinoma of Asian Origin. PLoS One. 2013;8(11):1-12. doi:10.1371/journal.pone.0080229

8. Yang L, Wang Y, Guo L, Wang L, Chen W, Shi B. The Expression and Correlation of iNOS and p53 in Oral Squamous Cell Carcinoma. Hindawi Publ Corp BioMed Res Int. 2015;2015(637853):1-9. http://dx.doi.org/10.1155/2015/637853.

9. Kaur J, Mannan R, Manjari M, Bhasin T, Sharma S. P53 Expression in Oral Squamous Cell Carcinoma as a Predictor of High Grade Malignancy and Regional Metastasis - an Experience From a Tertiary Care Hospital. Indian J Pathol Oncol. 2017;4(4):591-594. doi:10.18231/23946792.2017 .0127

10. Tjok GB. Association of P53 protein overexpression with clinicopathological features of oral squamous cell carcinoma patients in Bali. 2016;5(1):59-64. doi:10.15562/bmj.v5i1.206

11. Zhou J, Tao D, Xu Q, Gao Z, Tang D. Expression of E-cadherin and vimentin in oral squamous cell carcinoma. Int J Clin Exp Pathol. 2015;8(3):3150-3154.

12. Lim S-C. Predictive Markers for Late Cervical Metastasis in Stage I and II Invasive Squamous Cell Carcinoma of the Oral Tongue. Clin Cancer Res. 2004;10(1):166-172. doi:10.1158/10780432.CCR-0533-3

13. Balasundaram $P$, Singh MK, Dinda AK, Thakar A, Yadav R. Study of $\beta$-catenin, E-cadherin and vimentin in oral squamous cell carcinoma with and without lymph node metastases. Diagn Pathol. 2014;9(1):1-7. doi:10.1186/1746-1596-9-145

14. Ambar Kusuma Astuti, Irfan Prasetyo, Justisia Nafsi Yunita, Yuniardini Septorini Wimardhani FR. Profile of Human TERT and P73 in Oral Squamous Cell Carcinoma Cell Lines Compared to Normal Human Oral Mucosa: a Preliminary Study. J Dent Indones. 2011;18(1):10-16.

15. Tandon P, Dadhich A, Saluja H, Bawane S, Sachdeva S. The prevalence of squamous cell carcinoma in different sites of oral cavity at our Rural Health Care Centre in Loni, Maharashtra A retrospective 10-year study. Wspolczesna Onkol. 2017;21(2):178-183. doi:10.5114/wo.2017.66919 
16. Hernández-Guerrero JC, Jacinto-Alemán LF, Jiménez-Farfán MD, Macario-Hernández A, Hernández-Flores F, Alcántara-Vázquez A. Prevalence trends of oral squamous cell carcinoma. Mexico City's general hospital experience. Med Oral Patol Oral Cir Bucal. 2013;18(2):7-12. doi: $10.4317 /$ medoral. 18043

17. Herna G, Sebastia J. PROGNOSTIC SIGNIFICANCE OF P53 EXPRESSION IN ORAL SQUAMOUS CELL CARCINOMA WITHOUT NECK NODE METASTASES. Wiley Intersci. 2004;(January):22-30. doi:10.1002/hed.10339

18. Majumdar B, Patil S, Sarode SC, Sarode GS, Rao RS. Clinico-pathological prognosticators in oral squamous cell carcinoma: An update. Transl Res Oral Oncol. 2017;2:1-14. doi:10.1177/2057178X17738912

19. Jasmeet K, Rahul M, Mridu M, et al. Can p53 expression and staining intensity correlate with histopathological prognostic parameter and clinical staging in head and neck squamous cell carcinoma ? J Pathol Nepal. 2017;7:1141-1148. doi:10.3126/jpn.v7i2.17976 